\title{
RESEARCH ON THE IMPACT OF THE CORPORATE IMAGE ON THE COMPETITIVENESS OF INTERIOR DESIGN ENTERPRISES
}

\author{
Vyara Kyurova, ${ }^{1}$ Dilyana Yaneva ${ }^{2}$
}

\begin{abstract}
In striving to secure a competitive advantage in the market, companies endeavor to create a high level of trust and attachment of customers to the company. Building a positive image is a prerequisite for businesses to enhance their competitiveness. In this regard, the main objective of this paper is to identify measures of corporate image, competitiveness of enterprises, and the relationship between them. This paper uses statistical methods (variance, regression, and correlation analysis) to study the influence of corporate image on the competitiveness of enterprises in the field of interior design. A questionnaire method is used to gather the primary data. Examined indicators are assessed using a 7-point Likert scale. The results of the survey indicate a strong correlation between the level of corporate image and that of competitiveness of enterprises. The conclusion includes a summary concerning the use of the corporate image as an important tool for a sustainable market presence and achieving a strong competitive edge.
\end{abstract}

JEL Classification Numbers: M31, M20; DOI: http://dx.doi.org/10.12955/cbup.v5.973

Keywords: corporate image, competitiveness, interior design enterprises, indicators

\section{Introduction}

In a highly dynamic business environment of ever increasing competition and globalization, a business' main task is to search for new ways of enhancing their competitiveness. A successful implementation of market objectives requires enterprises to build positive attitudes, trust, and loyalty to their product, brand, and the company itself. This, in turn, lays the foundations of forming a corporate identity and achieving organizational objectives.

Building a positive corporate image is key to expanding influence and leadership in the market for any company. It is a major factor in forming consumer opinion and achieving the competitive advantage of enterprises.

In a highly competitive environment, only companies that implement effective marketing tools become successful. In this respect, the corporate image plays a crucial role as a strategic marketing tool. It allows the company to influence the consumer's purchasing decision, helps in attracting new clients and forming loyal customers, and these outcomes inevitably lead to an increase in sales and profit and foster the development and competitiveness of the company (Yaneva, 2016).

In this context, a study examining the value of the corporate image would benefit management decisions with respect to improving the competitiveness of an enterprise based on its competitive advantages.

\section{Literature Review}

The corporate image is associated with the behavior and profile of a company (Olins, 2003). It defines the financial relations of the company, as well as the relations between stakeholders and consumers (Brun, 2002). In this respect, Jones and Sasser (1995) emphasized that consumer behavior correlates with loyalty to the company. Moreover, the image relates to the way stakeholders, not only perceive, but also interpret their experience, beliefs, values, and experiences of the organization (Wood, 2001). Thus, corporate image plays a prominent role in customer satisfaction and in influencing customer's willingness to lay trust in the company (Andreassen \& Lindestad, 1998).

The main goal in building the corporate image is the effectiveness of communication. According to Kim and Lee (2010) with the help of the corporate image, social responsibility and capability of the company are formed. A set of tools and instruments are used, such as ideas, symbols, and events (Schultz, 2007). Another way to achieve competitiveness is through advertising because it contributes to a better understanding of the corporate image. In this regard, Kiryakova-Dineva (2016, p. 217) particularly comments on "the relationship of symbols, images, and company names."

The corporate image is a targeted communication strategy and is a direct consequence of interpreting information (Venelinova, 2012). It consists of planned and unplanned verbal and visual elements that

\footnotetext{
${ }^{1}$ Faculty of Economics, South-West University "Neofit Rilski”, Blagoevgrad, Bulgaria, verivasileva@abv.bg

${ }^{2}$ Faculty of Economics, South-West University “Neofit Rilski”, Blagoevgrad, Bulgaria, d_janeva@swu.bg
} 
are conveyed by the corporation and are aimed at creating an impression on the viewer (Abratt, 1989). In this regard, Afanasiev (2003) views the corporate image as containing descriptive and evaluative components.

It should be recognized that the impact of the attractiveness of the offered products reflects the competitiveness of the enterprise, which can be considered a result of the specific behavior of the company. Gorbashko (2015) defines this competitiveness as the potential for efficient operation in the market to achieve certain competitive advantages. The Great Britain Department of Trade (1994) defined competitiveness as "the ability to produce the right goods and services of the right quality, at the right price, at the right time. It means meeting customers' needs more efficiently and more effectively than other firms" (cited in Edmonds, 2000, p. 20). The Dictionary of Business and Management (Law, 2009) views competitiveness as the ability of an organization to compete successfully with its commercial rivals. Therefore, the analysis and evaluation of competitors are ongoing conditions, allowing the company to achieve the best market position and to meet the needs of consumers fully.

Filipova (2004) contended that today, among the main competitive factors that determine competitiveness, such as price, quality, technology, innovation, and time, corporate image is gaining increasing importance.

Building a corporate image is a fundamental tool of management for marketing enterprises in the field of interior design. This activity is crucial for boosting up consumer loyalty and evolving the corporate's competitive advantage and competitiveness.

Revealing the importance of a corporate image for the competitiveness of an enterprise requires appropriate measuring methods. The scientific literature suggested several approaches.

For example, Islam (2010) offered an evaluation based on the business name, architecture, and products or services. Kim and Lee (2010) emphasized service quality, satisfaction, and customer loyalty. Certain authors considered the corporate image as part of communication, and on this basis, they offered an assessment based on strategic intent, mission, vision, goals, and identity (Leuthesser \& Kohli, 1997; Van Riel \& Balmer, 1997).

Regarding competitiveness, certain authors offered an evaluation based on corporate flexibility (Galbraith, 1990; Rumelt, 1982; Bruning \& Lockshin, 2000; Pettigrew, 1987), product quality (Kumar, Motwani \& Stecke, 1999a; 1999b; Swan \& Targhavi, 1992), and return on assets (Besanko, 1996; Goddagd \& Wilson, 1996; Mueller, 1990; Waring, 1996). Others referred to the level of resource productivity (Porter, 1998; Allen, 1996), level of quality, price, service, and return on assets (Skinner, 1996), as well as marketing experience (Pratten, 1991). A comprehensive and accurate system of indicators was offered by Velev (2004) in relation to enterprises: product competitiveness; labor productivity; financial performance; innovation; change in the production volume; production and marketing flexibility; and adaptability to the market.

\section{Data and Methodology}

The study used data from a questionnaire-based survey, conducted in November to December 2016, of 28 enterprises in the field of interior design in Bulgaria. This research instrument was used because of its adequacy regarding the specifics of both the study topic and the data being sought. A qualitative assessment of the corporate image and competitiveness of enterprises in the field of interior design followed.

Each indicator characterizing the corporate image and competitiveness of enterprises in the field of interior design was assessed by respondents using a 7-point Likert scale, including estimates of 1 (very poor) to 7 (exceptional). Averages for each indicator were calculated and used in analyses.

For assessing the competitiveness of enterprises, the study used the indicators suggested by Velev (2004), since these were considered the most comprehensive and accurate system for the study.

Dispersion (Fisher Distribution), linear regression, and correlation analyses were used to explore the relationship between corporate image and competitiveness of enterprises.

The presence or absence of correlation between corporate image and competitiveness of enterprises was established using an analysis of variance (ANOVA). The test was based on the following hypotheses: 
- $H_{0}$ - there is no statistically significant difference between the level of corporate image and competitiveness of enterprises;

- $H_{1}$ - differences in the level of value of the corporate image substantially affect the competitiveness of the surveyed enterprises.

A single factor regression analysis was conducted to test the relationship between the corporate image of enterprises in the field of interior design, the factor $\left(x_{i}\right)$, and their competitiveness, the result $\left(y_{i}\right)$.

A correlation analysis (coefficient of Pearson) was used to determine the strength of the relationship between the variables of corporate image and competitiveness of enterprises. To define what part of the overall changes in (y) was due to variations in the studied factors, the coefficient of determination was calculated.

\section{Results and Discussion}

The survey results regarding the level of value of the corporate image showed that a relatively low share of businesses defined their image as poor (14.3\%). In particular, $25.0 \%$ of businesses rated it as fair, and $28.6 \%-32.1 \%$ as good to very good. It should be noted that none of the surveyed enterprises indicated an excellent level of value of the corporate image.

The dispersion analysis assessed the effect of the corporate image on competitiveness. The estimated value of the empirical feature was 16.70 (F - Fisher criterion) with a theoretical value of 3.07 at the level of significance $\alpha=0,05$. Thus the null hypothesis was rejected, and the alternative hypothesis confirmed. Hence, differences in the level of significance of the corporate image substantially affect the competitiveness of the surveyed enterprises, i.e., in the field of interior design, based on the assessments given by the respondents.

The regression analysis results $(b=0.74)$ revealed a positive relationship between the assessments of corporate image and competitiveness of the surveyed enterprises, in the field of interior design. Thus, the increase in the average evaluation of the corporate image by a unit resulted in an average increase in the grade of the competitiveness of enterprises in the field of interior design by 0.74 .

The estimated value of the correlation coefficient of Pearson $(r=0.84)$ showed a strong correlation between corporate image and competitiveness of enterprises in the said field.

The resulting coefficient of determination (0.7056) indicated a substantial part (70.56\%) of the total change in the result, 'competitiveness,' was due to variations in the factor, 'corporate image.'

\section{Conclusion}

The study results suggest that the corporate image has a significant impact on the competitiveness of the surveyed enterprises in the field of interior design. The increase in the assessment of corporate image by one unit led to an increase in the assessment of the competitiveness of enterprises in the field of interior design by 0.74 . The presence of a strong correlation between the level of corporate image and competitiveness of enterprises was observed. It was found out that the majority $(70.56 \%)$ of the total change in the competitiveness was due to change in the corporate image. Hence, the importance of corporate image for the competitiveness of enterprises in the field of interior design requires continuous, targeted management actions, aimed at optimizing marketing activities and developing and implementing an effective, adequate, and innovative strategy to deal with the dynamic changes in the competitive environment. Possibly, enterprises in the field of interior design need to embrace innovation as a strategic priority with the aim of effective use of a corporate image as a prerequisite for further gaining competitive advantage, as well as to preserve and increase market share.

\section{References}

Abratt, R.A. (1989). A new approach to the corporate image management process. Journal of marketing management, Johannesburg, 5 (1). 63-76.

Afanasiev, S.V. (2003). Formirovanie korporativnogo imidzha kak osnovnaya sostavlyashtaya PR - strategii. Marketing, MGU, Moskva.

Allen, L., \& Pantzalis, C. (1996). Valuation of the Operating Flexibility of Multinational Corporations. Journals of International Business Studies, 27 (4), 633-653.

Andreassen, T. W., \& Lindestad, B. (1998). Customer loyalty and complex services: The impact of corporate image on quality, customer satisfaction and loyalty for customers with varying degrees of service expertise. International Journal of Service Industry Management, 9, (1), 7-23. 
Besanko, D., Dranove, D., \& Shanley, M. (1996). The Economics of Strategy. John Wiley \& Sons, New York. Boulding, K. E. (1977). The Image: Knowledge in life and society. Ann Arbor: University of Michigan Press.

Brown, T. J., \& Dacin, P. A. (1997). The company and the product: Corporate associations and consumer product responses. Journal of Marketing, 61, 68-84.

Brun, M. (2002). Creating a New Identity for France Telecom, Corporate and organizational identities: Integrating strategy, marketing, communication, and organizational perspectives, In: B. Moingeon, G. Soenen (eds.), London, Routledge.

Bruning, E., \& Lockshin, L. (2000). Fundamental Elements in the Definition of Organizational Competitiveness, Gestion, 11 (3), 55-70.

Edmonds, T. (2000). Regional Competitiveness \& the Role of the Knowledge Economy, House of Commons Library. Research paper. London: Research Publications Office.

Filipova, M. (2004). Povishavane konkurentosposobnostta na pivovarnite predpriyatiya. Korect, Sofiya.

Galbraith, C. (1990). Transferring Core Manufacturing Techniques in High-Tech Firms, California Management Review, 32 (4), 56-70.

Goddagd, J., \& Wilson, J. (1996). Persistence of Profits for UK Manufacturing and Service Sector Firms. The Service Industries Journal, 16 (2).

Gorbashko, E. A., Maksimtsev, I. A., Alekseevna, YU. R., \& Chetyrkina, N. YU. (2015). Upravlenie konkurentosposobnost'yu (teoriya i praktika). Yurăt, Moskva.

Hair, J. F., Anderson, R. E., Tatham, R. L. \& Black, W. C. (2006). Multivariate Data Analysis, 5th Ed., Upple Saddle River, New Jersey: Prentice Hall.

Islam, M. S. (2010). The analysis of customer loyalty in Bangladeshi mobile phone industry. World Journal of Management, 2(2), 130-145.

Jones, T., \& Sasser, W.E. (1995). Why satisfied customers defect. Harvard Business Review, 73 (6), 88-99.

Kaloyanov, T. (2004). Statistika. Trakiya-M, Sofiya.

Kim, Y., \& Lee, J. (2000). Relationship between corporate image and customer loyalty in mobile communications service markets. Africa Journal of Business Management, 4(18), 4035-4041.

Kiryakova-Dineva, T. (2016). The interplay of visual images in food advertising. Analele Universităţii din Craiova. Seria Ştiinţe Filologice. Lingvistică, 38 (1-2), 215-226.

Kumar, A., J. Motwani, K. Stecke, (1999a). Quantitive Measurement of Organizational Competitiveness Through Quality, 30-th Decision Sciences Conference Proceedings, New Orleans.

Kumar, A., K. Stecke, J. Motwani (1999b). A Quality Index-Based Methodology for Improving Competitiveness: Analytical Development and Empirical Validation, Working Rarer Series - Working Paper 01-015, University of Michigan Business School.

Law, J. (2009). A Dictionary of Business and Management. Oxford University Press.

Leuthesser, L., C. Kohli, (1997). Corporate identity: the role of mission statements, Business Horizons, 40, 59-66.

Mueller, D. (1990). The Dynamics of Company Profits, Cambridge University Press: Cambridge, MA.

Nikolova, N. (2010). Statistika. Obshta teoriya. Avangard Prima, Sofiya.

Nosova, N. S. (2015). Konkurentnaya strategiya kompanii, ili marketingovye metody konkurentnoĭ bor'by. Dashkov i K, Moskva.

Olins, W. (2003). Corporate identity: the myth and reality. In: Perspective on identity, image, reputation, corporate branding and corporate-level marketing. In Balmer, J. M. T., S. A. Greyser, Revealing the Corporation: Perspectives on Identity, Image, Reputation, Corporate Branding and Corporate-level Marketing, London: Routledge, 55-61.

Pettigrew, A. (1987). Context and Action in the Transformation of the Firm, Journal of Management Studies, 24 (6), 649670.

Porter, M. (1998). On Competition, Harvard Business Press.

Pratten, C. (1991). The Competitiveness of Small Firms, Occasional Paper 57, Department of Applied Economics, University of Cambridge, UK: Cambridge University Press.

Rancheva, E. (2010). Statistika, Tekhnologika. Plovdiv

Rumelt, R. (1982). Diversification Strategy and Profitability. Strategic Management Journal, 3(4), 359-369,

Schultz, M. (2007). Organizational Image, International Encyclopedia of Organizational Studies. Sage Publications, London.

Skinner, W. (1996). Manufacturing Strategy on the "S" Curve. Production and Operations Management, 5(1), 3-14,

Sǔikova, Iv., S. Todorova (1994). Statisticheskoto izsledvane (postanovka, metodi, otsenka na rezultatite). Lyuren, Sofiya.

Swann, P., M. Targhavi (1992). Measuring Price and Quality Competitiveness - A Study of Eighteen British Product Markets. Brookfield, Vermont, Ashgate Publishing Company.

Van Riel, C.B.M., J.M.T. Balmer (1997). Corporate identity: the concept, its measurement and management. European Journal of Marketing, 31 (5/6), 340-55

Velev, M. (2004). Otsenka i analiz na firmenata konkurentosposobnost. Softtrĕ̌d, Sofia.

Venelinova, N. (2012). Definitivni aspekti na vrŭzkata „imidzh “- „identichnost “. Nauchni trudove na Rusenskiya universitet, 51 (5.2), 135-142.

Waring, G. (1996). Industry Differences in the Persistence of Firm-specific returns. The American Economic Review, 86 (5), 1253-1265.

Wood, E. (2001). Corporate identity. In: The Public Relations Handbook. Alison Theaker, Routledge, L.

Yaneva, D. (2016). Corporate image - a factor for company development, Entrepreneurship, 4 (2), 248-255. 